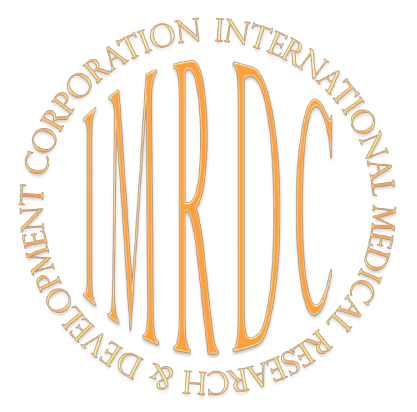

\title{
Methods for Treatment of Malignant Pleural Effusion
}

\author{
Alexei L. Charyshkin, $\mathrm{PhD}, \mathrm{ScD}^{1 *}$; Ekaterina A. Kuzmina ${ }^{2}$; \\ Bulat I. Khusnutdinov ${ }^{1,3}$; Evgeniy A.Toneev ${ }^{1,3}$; Vladimir I. Midlenko, $\mathrm{PhD}, \mathrm{ScD}^{1}$ \\ ${ }^{1}$ Ulyanovsk State University, Ulyanovsk, Russia \\ ${ }^{2}$ Pirogov Russian National Research Medical University, Moscow, Russia \\ ${ }^{3}$ Regional Clinical Oncology Center, Ulyanovsk, Russia
}

\begin{abstract}
This brief review provides up-to-date information on the management of malignant pleural effusions (MPE). In general, selection of the most appropriate treatment approach should be individualized. Management of MPE relies on tumor type, pulmonary re-expansion, performance status, symptoms, and life expectancy. Pleurodesis and IPC placement are two effective treatments recommended for recurrent MPE, both of which can effectively improve dyspnea and quality of life of patients. Other options such as intrapleural therapies, radiation therapy, and pleuroperitoneal shunting are alternative treatments. However, most of these treatments are temporary, and MPE would recur soon. Hence, further palliative treatments to effectively control pleural effusions and relieve symptoms are necessary. (International Journal of Biomedicine. 2020;10(1)16-19.)
\end{abstract}

Key Words: malignant pleural effusions $\bullet$ thoracentesis $\bullet$ pleurodesis $\bullet$ indwelling pleural catheters

$\mathrm{M}$ ore than 300,000 patients in the Russian Federation die every year from malignant neoplasms, which thus occupy the third place in the mortality structure of the country's population and remain the most important medical and social problem.

One of the most common complications of tumor diseases is malignant pleural effusions (MPE). In the structure of the general incidence, the proportion of pleurisy reaches $4 \%$, while the oncological etiology accounts for $63 \%$ of all exudative pleurisy.

The majority of MPE is caused by metastatic disease: most commonly lung cancer in men and breast cancer in women. ${ }^{(1)}$ These two cancers combined account for $50 \%-65 \%$ of all MPE. ${ }^{(2-5)}$ Mesothelioma is the most common type of primary pleural tumor and is associated with MPE in more than $90 \%$ of cases. ${ }^{(3)}$ In $12 \%$ of patients with MPE, it is not possible to establish the nature of the primary tumor. The presence of MPE indicates an advanced stage of the disease with a median life expectancy of 3 to 12 months, depending on the stage and type of underlying malignancy. ${ }^{(6)}$ There are more than 100,000 new cases of MPE yearly in Russia.

*Corresponding author: Prof. Alexei L. Charyshkin, PhD, $S c D$, Head of the Faculty Surgery Department, Institute of Medicine, Ecology and Physical Education, Ulyanovsk State University. Ulyanovsk, Russia.E-mail: charyshkin@yandex.ru
Although the first randomized trial for MPE treatment methods was performed in $1977,{ }^{(7)}$ the optimum management of the disease remains under debate and research. In MPE patients, dyspnea is the most common presenting symptom followed by chest discomfort and cough. ${ }^{(3,8,9)}$ The quality of life is improved by local treatment methods, which not only help reduce the symptoms of pleurisy, but also extend the life of patients from several months to 1-3 years. Prior to considering any definitive treatment intervention, all patients with MPE should undergo a therapeutic aspiration to assess symptomatic improvement and rate of fluid reaccumulation.

During the past two decades, there has been a change in direction in MPE research and management. ${ }^{(1)}$ Historically, studies were focused on halting pleural fluid accumulation and often employed aggressive surgical methods (pleurectomy); ${ }^{(10-12)}$ and most clinical trials ${ }^{(13,14)}$ aimed at identifying the best agent that would achieve obliteration of the pleural space (pleurodesis). The most common end-point of these early studies was radiological improvement at 1-3 months post-pleurodesis, without consideration of the patients' symptoms. ${ }^{(15)}$ Currently, the treatment approach for patients with MPE is mainly aimed at alleviating their symptoms and improving quality of life indicators, which is a key goal of treatment. ${ }^{(16)}$

In general, selection of the most appropriate treatment approach should be individualized. Management of MPE relies on tumor type, pulmonary re-expansion, performance 
status, symptoms, and life expectancy. Asymptomatic patients with a known tumor type who are responding well to systemic therapies should be under observation. ${ }^{(3)}$ Some cancers, such as small cell lung cancer, lymphoma, breast cancer, prostate, and ovarian cancer, may respond well to chemotherapy. ${ }^{(3,17-19)}$

Patients who have a life expectancy of more than 3 months or are resistant to chemotherapy should be given palliative treatments,(20) such as observation, thoracentesis, indwelling pleural catheters (IPCs), pleurodesis, intrapleural therapies, radiation therapy, and pleuroperitoneal shunting (PPS). ${ }^{(3,20-22)}$

Thoracentesis is generally safe, especially if it is performed with ultrasound guidance. ${ }^{(23)}$ Thoracentesis is a good choice for patients with advanced disease and a short life expectancy (1-3 months), slow pleural fluid reaccumulation, or poor performance status that precludes the patient from other interventional therapies. ${ }^{(21,24)}$ The amount of fluid evacuated by pleural aspiration will be guided by patient symptoms and should be limited to $1.5 \mathrm{~L}$ on a single occasion. ${ }^{(3,25)}$ Pneumothorax is one of the most common complications associated with thoracentesis, with an incidence rate as high as 20\%-39\%.(26) Re-expansion pulmonary edema occurs rapidly if the removed fluid is more than 1.5L. ${ }^{(27,28)}$ As known, almost all patients experience recurrence of symptoms and effusions within 1 month. ${ }^{(3,29)}$ Although thoracentesis does not improve survival, it can significantly improve the patient's condition and avoid hospitalization.

Pleurodesis refers to the process of chemically or mechanically inducing pleural inflammation to the visceral and parietal pleura to obliterate the area and prevent the accumulation of air or liquid in the pleural space. Instillation of the sclerosing agent is thereafter followed by a profound inflammatory response between the layers, which, in turn, result in fibrin accumulation and pleural fibrosis. Pleurodesis is a better option for recurrent MPE than thoracocentesis unless the patient has a very poor performance status, a short life expectancy, or a trapped lung.(27) A variety of different chemicals (e.g. talc, bleomycin, tetracycline, iodopovide) and bacterial products (Corynobactum parvum, Streptococcus pyogenes, Staphylococcus aureus, and others) have been used in clinical studies to achieve pleurodesis. ${ }^{(30-33)}$ The profound inflammatory response they may result in adverse events, such as pain and fever, but it is believed that the level of inflammation correlates with the likelihood of successful pleurodesis. ${ }^{(34)}$ Chest pain and fever are the most common complications of chemical pleurodesis. Other complications include a cough, empyema, local site infection, trapped lung, and acute respiratory distress syndrome. ${ }^{(29)}$ The type of sclerosant, the method of administration and the method of selecting patients to be treated with pleurodesis are still unclear. Talc is the most effective sclerosant available for pleurodesis, especially graded talc, which can be delivered as slurry via an intercostal catheter or by dry-powder poudrage during a thoracoscopy. ${ }^{(3)}$ Talc was first used for pleurodesis in 1935. ${ }^{(35)}$ It has been proven that graded preparations (as opposed to small particle talc) should be used to minimize systemic dissemination of talc particles and the risk of acute respiratory distress syndrome. ${ }^{(36,37)}$
Results from the largest randomized trial in MPE revealed that the success rates of talc slurry and talc poudrage are not significantly different. ${ }^{(38,39-41)}$ A subgroup analysis of patients with lung and breast cancer suggested a better success rate for talc poudrage. ${ }^{(38)}$ On the contrary, a metanalysis performed by $\mathrm{Xia} \mathrm{H}$ et al. ${ }^{(42)}$ demonstrated that talc poudrage was superior to talc slurry in pleurodesis success. According to Zhestkov\& Iaduta, ${ }^{(43)}$ in a series of 132 patients, the effectiveness of the method was $97.7 \%$, pleurisy recurrence was diagnosed in only 3 patients, and no serious postoperative complications were recorded. Domestic authors recommend talc pleurodesis with daily exudation of pleural effusion up to $300 \mathrm{ml}$, bleomycin pleurodesis with daily exudation up to $700 \mathrm{ml}$ and combined pleurodesis at more than $700 \mathrm{ml}$; in case of failure, pleurodesis by videothoracoscopy is recommended.

IPCs have gained popularity during the last decade as they offer ambulatory management, thereby minimizing hospital stay and healthcare costs. ${ }^{(44)} \mathrm{An}$ IPC is a silicone tube placed in the pleural cavity and tunneled subcutaneously. The proximal end of the exposed tube has a one-way valve, which connects to drainage bottles. Drainage is guided by symptoms and is patient-driven, offering a sense of control to most patients. The optimal schedule of MPE drainage through an IPC is still not clear. This system provides the patients, or people who care for them, complete control over the removal of fluid from the pleural cavity. Such systems are rarely used in Russia; domestic scientific literature on this issue could not be found. The British Thoracic Society Pleural Disease Guideline recommends the use of IPCs in those patients with MPE that have failed pleurodesis or in those with trapped lung (unsuitable for pleurodesis). ${ }^{(3)}$ A meta-analysis of 1348 patients with MPE treated with IPCs revealed that $95.6 \%$ had symptomatic improvement and $45.6 \%$ achieved spontaneous pleurodesis after a median of 52 days. ${ }^{(45)}$ The TIME2 randomised controlled trial showed that IPCs achieved control of breathlessness and quality of life comparable to talc pleurodesis, median length of hospitalization was significantly shorter in the IPC group than talc group ( 0 vs. 4 days; $P<0.001)$. Fewer patients with IPCs required further pleural procedures than talc group ( $6 \%$ vs. $22 \%, P=0.03) .{ }^{(16)}$ Another prospective multicenter study achieved the same results. ${ }^{(46)}$ There is ongoing research on possible combinations of IPC with sclerosant agents in order to enhance pleurodesis success. ${ }^{(47)}$ Recent data also provide reassurance on the safety of IPC use, with a risk of death from pleural infection below $0.3 \%{ }^{\left({ }^{(4)}\right)}$ As IPCs offer longterm access to the pleural cavity, they represent ideal potential portals for local drug delivery.

There is another method proposed by Plaksin and Farshatova $^{(49)}$ for effective control of pleural effusions and obliteration of the pleural cavity: Through a drainage tube installed during thoracoscopy or during drainage of the pleural cavity, $50 \mathrm{ml}$ of a $1 \%$ lidocaine solution is injected into the pleural cavity for pain relief, after which the tube is closed for 20 minutes. After that, 40-80 $\mathrm{ml}$ of a previously prepared mixture consisting of $1 \%$ iodopyron solution and $40 \%$ glucose solution in a 1:4 ratio is injected into the drainage tube using a syringe. The drainage is closed for 2 hours. At this time, the patient repeatedly changes the position of the body 
so that the drugs get into all parts of the hemithorax. Then the drainage is opened and active aspiration is continued. Drainage is removed from the pleural cavity with a decrease in the volume of exudation to $\leq 100 \mathrm{ml}$ of effusion per day. The disadvantages of this method of treatment are (1) insufficient analgesia; since there is no premedication (anesthesia before surgical procedures), anesthetic (lidocaine) is administered once; and (2) the use of a standard drainage tube of the same diameter without through holes, which does not allow effective irrigation of the pleural cavity with drugs, thereby reducing their effectiveness.

In conclusion, pleurodesis and IPC placement are two effective treatments recommended for recurrent MPE, both of which can effectively improve dyspnea and quality of life of patients. Other options such as intrapleural therapies, radiation therapy, and PPS are alternative treatments. However, most of these treatments are temporary, and MPE would recur soon. Hence, further palliative treatments to effectively control pleural effusions and relieve symptoms are necessary.

\section{References}

1. Psallidas I, Kalomenidis I, Porcel JM, Robinson BW, Stathopoulos GT. Malignant pleural effusion: from bench to bedside. Eur Respir Rev. 2016;25(140):189-98. doi: 10.1183/16000617.0019-2016.

2. Mongardon N, Pinton-Gonnet C, Szekely B, MichelCherqui M, Dreyfus JF, Fischler M. Assessment of chronic pain after thoracotomy: a 1-year prevalence study. Clin J Pain. 2011;27(8):677-81. doi: 10.1097/AJP.0b013e31821981a3.

3. Roberts ME, Neville E, Berrisford RG, Antunes G, Ali NJ; BTS Pleural Disease Guideline Group. Management of a malignant pleural effusion: British Thoracic Society pleural disease guideline 2010. Thorax. 2010;65 Suppl 2:ii32-40. doi: 10.1136/thx.2010.136994.

4. Kolschmann S, Ballin A, Gillissen A. Clinical efficacy and safety of thoracoscopic talc pleurodesis in malignant pleural effusions. Chest 2005;128(3):1431-5.

5. Antony VB, Loddenkemper R, Astoul P, Boutin C, Goldstraw P, Hott J, et al. Management of malignant pleural effusions. Eur Respir J. 2001;18(2):402-19.

6. Kasapoglu US, Arınç S, Gungor S, Irmak I, Guney P, Aksoy F, et al. Prognostic factors affecting survival in nonsmall cell lung carcinoma patients with malignant pleural effusions. Clin Respir J. 2016;10(6):791-799. doi: 10.1111/ crj.12292.

7. Mejer J, Mortensen KM, Hansen HH. Mepacrine hydrochloride in the treatment of malignant pleural effusion. A controlled randomized trial. Scand J Respir Dis. 1977;58(6):319-23.

8. Yserbyt J, Dooms C. Malignant pleurisy and palliative therapy. Belg J Med Oncol. 2015;9:272-8.

9. Martínez-Moragón E, Aparicio J, Sanchis J, Menéndez R, Cruz Rogado M, Sanchis F. Malignant pleural effusion: prognostic factors for survival and response to chemical pleurodesis in a series of 120 cases. Respiration. 1998;65(2):108-13.

10. Wierman WH, Spencer JR. The role of thoracotomy and parietal pleurectomy in the diagnosis and treatment of pleural effusions. Am Surg. 1961;27:383-7.

11. Jensik R, Cagle JE Jr, Milloy F, Perlia C, Taylor S, Kofman
S, Beattie EJ Jr. Pleurectomy in the treatment of pleural effusion due to metastatic malignancy. $\mathbf{J}$ Thorac Cardiovasc Surg. 1963;46:322-30

12. Beattie EJ Jr. The treatment of malignant pleural effusions by partial pleurectomy. Surg Clin North Am. 1963;43:99-108 13. Jones GR. Treatment of recurrent malignant pleural effusion by iodized talc pleurodesis. Thorax 1969;24(1):69-73 14. Reshad K, Inui K, Takeuchi Y, Takahashi Y, Hitomi S. Treatment of malignant pleural effusion. Chest 1985;88(3):393-7. 15. Davies HE, Lee YC. Management of malignant pleural effusions: questions that need answers. Curr Opin Pulm Med. 2013;19(4):374-9. doi: 10.1097/MCP.0b013e3283615b67.

16. Davies HE, Mishra EK, Kahan BC, Wrightson JM, Stanton $\mathrm{AE}$, Guhan A, et al. Effect of an indwelling pleural catheter vs chest tube and talc pleurodesis for relieving dyspnea in patients with malignant pleural effusion: the TIME2 randomized controlled trial. JAMA. 2012;307(22):2383-9. doi: 10.1001/ jama.2012.5535.

17. Egan AM, McPhillips D, Sarkar S, Breen DP. Malignant pleural effusion. QJM. 2014;107(3):179-84. doi: 10.1093/ qjmed/hct245.

18. Kastelik JA. Management of malignant pleural effusion. Lung. 2013;191(2):165-75. doi: 10.1007/s00408012-9445-1.

19. Bychkov MB. [Tumor pleurisy (differential diagnosis and treatment)]. Russkii Medizinskii Zhurnal.1999;10:3. [Article in Russian].

20. Zarogoulidis K, Zarogoulidis P, Darwiche K, Tsakiridis K, Machairiotis N, Kougioumtzi I, et al. Malignant pleural effusion and algorithm management. J Thorac Dis. 2013;5 Suppl 4:S413-9. doi: 10.3978/j.issn.2072-1439.2013.09.04.

21. Kaifi JT, Toth JW, Gusani NJ, Kimchi ET, StaveleyO'Carroll KF, Belani CP, Reed MF. Multidisciplinary management of malignant pleural effusion. J Surg Oncol. 2012;105(7):731-8. doi: 10.1002/jso.22100.

22. Thomas JM, Musani AI. Malignant pleural effusions: a review. Clin Chest Med. 2013;34(3):459-71. doi: 10.1016/j. ccm.2013.05.004.

23. Yazdanbod A, Salehifar A, Maleki N, Habibzadeh S, Tavosi Z. Successful use of central venous catheters in the management of recurrent malignant pleural effusions: one new option. Support Care Cancer. 2015;23(8):2267-71. doi: 10.1007/s00520-014-2595-3.

24. Beyea A, Winzelberg G, Stafford RE. To drain or not to drain: an evidence-based approach to palliative procedures for the management of malignant pleural effusions. J Pain Symptom Manage. 2012;44(2):301-6. doi: 10.1016/j. jpainsymman.2012.05.002.

25. Feller-Kopman D, Walkey A, Berkowitz D, Ernst A. The relationship of pleural pressure to symptom development during therapeutic thoracentesis. Chest. 2006;129(6):1556-60. 26. Grogan DR, Irwin RS, Channick R, Raptopoulos V, Curley FJ, Bartter T, Corwin RW. Complications associated with thoracentesis. A prospective, randomized study comparing three different methods. Arch Intern Med. 1990; 150(4):873-7. 27. Quinn T, Alam N, Aminazad A, Marshall MB, Choong CK. Decision making and algorithm for the management of pleural effusions. Thorac Surg Clin. 2013;23(1):11-6, v. doi: 10.1016/j.thorsurg.2012.10.009.

28. Feller-Kopman D.Therapeutic thoracentesis: the role of ultrasound and pleural manometry. Curr Opin Pulm Med. 2007;13(4):312-8.

29. Nam HS. Malignant pleural effusion: medical approaches 
for diagnosis and management. Tuberc Respir Dis (Seoul). 2014;76(5):211-7. doi: 10.4046/trd.2014.76.5.211.

30. Agarwal R, Paul AS, Aggarwal AN, Gupta D, Jindal SK. A randomized controlled trial of the efficacy of cosmetic talc compared with iodopovidone for chemical pleurodesis. Respirology. 2011;16(7):1064-9. doi: 10.1111/j.14401843.2011.01999.x.

31. Kishi K, Homma S, Sakamoto S, Kawabata M, Tsuboi E, Nakata K, Yoshimura K. Efficacious pleurodesis with OK432 and doxorubicin against malignant pleural effusions. Eur Respir J. 2004;24(2):263-6.

32. Ren S, Terman DS, Bohach G, Silvers A, Hansen C, Colt $\mathrm{H}$, Sahn SA. Intrapleural staphylococcal superantigen induces resolution of malignant pleural effusions and a survival benefit in non-small cell lung cancer. Chest. 2004;126(5):1529-39.

33. Ukale V, Agrenius V, Hillerdal G, Mohlkert D, Widström O. Pleurodesis in recurrent pleural effusions: a randomized comparison of a classical and a currently popular drug. Lung Cancer. 2004;43(3):323-8.

34. Thomas R, Francis R, Davies HE, Lee YC. Interventional therapies for malignant pleural effusions: the present and the future. Respirology. 2014;19(6):809-22. doi: 10.1111/ resp. 12328 .

35. Bethune N. Pleural poudrage: new technique for the deliberate production of pleural adhesion as preliminary to lobectomy. J Thorac Surg. 1935;4:251.

36. Janssen JP, Collier G, Astoul P, Tassi GF, Noppen M, Rodriguez-Panadero F, et al. Safety of pleurodesis with talc poudrage in malignant pleural effusion: a prospective cohort study. Lancet. 2007;369(9572):1535-1539. doi: 10.1016/ S0140-6736(07)60708-9.

37. Maskell NA, Lee YC, Gleeson FV, Hedley EL, Pengelly G, Davies RJ. Randomized trials describing lung inflammation after pleurodesis with talc of varying particle size. Am J Respir Crit Care Med. 2004;170(4):377-82.

38. Dresler CM, Olak J, Herndon JE 2nd, Richards WG, Scalzetti E, Fleishman SB, et al.; Cooperative Groups Cancer and Leukemia Group B; Eastern Cooperative Oncology Group; North Central Cooperative Oncology Group; Radiation Therapy Oncology Group. Phase III intergroup study of talc poudrage vs talc slurry sclerosis for malignant pleural effusion. Chest. 2005;127(3):909-15.

39. Terra RM, Junqueira JJM, Teixeira LR, Vargas FS, PêgoFernandes PM, Jatene FB. Is full postpleurodesis lung expansion a determinant of a successful outcome after talc pleurodesis?
Chest. 2009;136(2):361-368. doi: 10.1378/chest.08-2448. 40. Yim AP, Chan AT, Lee TW, Wan IY, Ho JK. Thoracoscopic talc insufflation versus talc slurry for symptomatic malignant pleural effusion. Ann Thorac Surg. 1996;62(6):1655-8.

41. Rahman NM, Davies HE, Salzberg M, Truog P, Midgely $\mathrm{R}$, Kerr D, et al. Use of lipoteichoic acid-T for pleurodesis in malignant pleural effusion: a phase I toxicity and doseescalation study. Lancet Oncol. 2008;9(10):946-52. doi: 10.1016/S1470-2045(08)70205-5.

42. Xia H, Wang XJ, Zhou Q, Shi HZ, Tong ZH. Efficacy and safety of talc pleurodesis for malignant pleural effusion: a meta-analysis. PLoS One. 2014;9(1):e87060. doi: 10.1371/ journal.pone.0087060.

43. Zhestkov KG, Iaduta RT. [The role and place of talc in malignant pleuritis management (literature review)]. Pirogov Russian Journal of Surgery. 2016;(1):40-44. [Article in Russian].

44. Clive AO, Bhatnagar R, Psallidas I, Maskell NA. Individualised management of malignant pleural effusion. Lancet Respir Med. 2015;3(7):505-6. doi: 10.1016/S22132600(15)00183-6.

45. Van Meter ME, McKee KY, Kohlwes RJ. Efficacy and safety of tunneled pleural catheters in adults with malignant pleural effusions: a systematic review. J Gen Intern Med. 2011;26(1):70-6. doi: 10.1007/s11606-010-1472-0.

46. Putnam JB Jr, Walsh GL, Swisher SG, Roth JA, Suell DM, Vaporciyan AA, et al. Outpatient management of malignant pleural effusion by a chronic indwelling pleural catheter. Ann Thorac Surg. 2000;69(2):369-75.

47. Bhatnagar R, Kahan BC, Morley AJ, Keenan EK, Miller RF, Rahman NM, Maskell NA. The efficacy of indwelling pleural catheter placement versus placement plus talc sclerosant in patients with malignant pleural effusions managed exclusively as outpatients (IPC-PLUS): study protocol for a randomised controlled trial. Trials. 2015;16:48. doi: 10.1186/s13063-015-0563-y.

48. Fysh ETH, Tremblay A, Feller-Kopman D, Mishra EK, Slade M, Garske L, et al. Clinical outcomes of indwelling pleural catheter-related pleural infections: an international multicenter study. Chest. 2013;144(5):1597-1602. doi: 10.1378/ chest.12-3103.

49. Plaksin SA, Farshatova LI. A method for the treatment of exudative pleurisy. Patent for Invention RUS No. 2666401. Application No. 2017122884 dated 06/28/2017. Publ. 09/07/2018; bulletin No. 25. [In Russian]. 